Final version:

Borland, H. and Lindgreen, A., (2013), "Sustainability, epistemology, ecocentric business and marketing strategy: ideology, reality, and vision", Journal of Business Ethics, Vol. 117, No. 1, pp. 173-187. (ISSN 0167-4544)

For full article, please contact LindgreenA@cardiff.ac.uk

\title{
Sustainability, Epistemology, Ecocentric Business and Marketing Strategy: Ideology, Reality, and Vision
}

\begin{abstract}
This conceptual article examines the relationship between marketing and sustainability through the dual lenses of anthropocentric and ecocentric epistemology. Using the current anthropocentric epistemology and its associated dominant social paradigm, corporate ecological sustainability in commercial practice and business school research and teaching is difficult to achieve. However, adopting an ecocentric epistemology enables the development of an alternative business and marketing approach that places equal importance on nature, the planet and ecological sustainability as the source of human and other species' well-being, as well as the source of all products and services. This article examines ecocentric, transformational business and marketing strategies epistemologically, conceptually and practically and thereby proposes six ecocentric, transformational, strategic marketing universal premises as part of a vision of and solution to current global un-sustainability. Finally, this article outlines several opportunities for management practice and further research.
\end{abstract}


Keywords: sustainability; ecocentric business, epistemology; transitional, transformational, marketing strategy, vision. 


\section{Introduction}

Sustainability and marketing make somewhat unusual bedfellows in intellectual discourse (Banerjee et al., 2009) in that they traditionally take opposite sides on the consumption continuum (Menon and Menon, 1997). Yet sustainability is advancing rapidly as a viable ideology — in political, economic, technological, and academic circles — even though research has only begun to understand it theoretically, empirically, or strategically (Bansal and Roth, 2000; Kilbourne et al., 2002; Sharma et al., 2010). Understanding the strategic nature of sustainability and how it influences the development of marketing theory is even less well documented (Kilbourne, 1998; Sharma et al., 2007; Varadarajan, 2010). Part of the issue may be that sustainability is rooted in several scientific disciplines and does not belong to any one.

Sustainability is, quintessentially, interdisciplinary and discussed using varied theories and laws, including systems theory, ecosystems theory, the laws of thermodynamics, and Gaia theory (Borland, 2009a). Collectively, these theories and laws seek to explain the behavior, homeostatic balance, and maintenance of life on Earth (Lovelock, 2000). However, the UN's World Commission on Environment and Development (1987) prompted widespread adoption of an anthropocentric view of sustainability (Purser et al., 1995; Sharma et al., 2007). This view, anthropocentric sustainability, prioritizes a human bias and has generated sub-disciplines such as environmental management, sustainable development, and environmental resource management (Porritt, 2007; Purser et al., 1995), which put human needs and wants-or further human expansion and development — above the survival and development needs of other species.

To delineate the properties of sustainability, Belz and Peattie (2009) instead suggest a framework that features a holistic and systems-based view, an open-ended timeframe, a global perspective that focuses on ecological sustainability rather than economic efficiency, and 
recognition of the intrinsic value of nature. Yet sustainability also demands recognition of the finite limits of nature as a source of resources and a repository of waste, and it distinguishes between (impossible) unlimited economic growth and sustainable growth, which implies a qualitative improvement in means and ends (Ekins, 2000; Guest, 2010) through improved health and well-being for all species. Because ecological sustainability implies a fundamentally different way of looking at the world, as well as marketing's place in it, it demands an expansion of the limits of marketing enquiry (Grönroos, 2007; Hult, 2011; Varey, 2010). That is, the marketing discipline must adopt a more macro focus and more multi-disciplinary methods (Cronin et al., 2011; Kilbourne, 1998; Mittelstaedt and Kilbourne, 2006; Varey, 2011).

The modern marketing philosophy, however, emphasizes greater consumption as a societal end-point (Schaefer and Crane, 2005), perpetuates an anthropocentric ideology, and aims to maximize corporate profits by satisfying the preferences and choices of individual consumer targets (Ellis et al., 2011). Such a view produces conventional, cradle-to-grave products and services that firms label "green" or "eco," misleading consumers into thinking they are helping the environment (Peattie, 1999). Curry (2011), though, delineates between "light green," "mid green," and "deep green" products and services. But perpetuating an anthropocentric ideology through conventional marketing activity cannot lead to sustainability (Hart and Milstein, 1999), especially in the face of exponential global population growth, resource depletion, overconsumption, waste accumulation, and habitat destruction. Addressing such manifestations of the excesses of human activity through existing mental filters and mind-sets will have little effect on future prospects (Bosselmann, 1995). 
We therefore consider a different approach to strategic marketing that is based on ecological sustainability and ecocentric epistemology. In so doing, this article examines whether strategic marketing truly can be reconceptualized on ecocentrism and ecological sustainability?

Ecological sustainability is defined as the capacity for continuance into the long-term future, by living within the constraints and limits of the biophysical world (Porritt, 2007). It represents a goal, endpoint, or desired destination for the human species as much as for any other species, and can be explained, defined, and measured scientifically. Sustainable development instead refers to the process for moving toward sustainability; it implies trying to achieve sustainability, but often seems poorly defined and difficult to measure. To achieve a sustainable human future, sustainable development generally includes social and economic elements, as well as environmental ones, though Porritt (2007) considers those elements secondary goals, because all else is conditional on living sustainably within the Earth's systems and limits. The pursuit of ecological sustainability thus is non-negotiable (Porritt, 2007; see also Mort, 2010).

The urgency of the ecological sustainability predicament drives the search for new ways of living and conducting business (Mort, 2010). Yet many corporate initiatives toward what firms perceive to be sustainability are simply efficiency drives or competitive moves (Unruh and Ettenson, 2010) - falling far short of actual strategies for ecological sustainability. To suggest true ecological sustainability strategies, we adopt an interdisciplinary, or transdisciplinary (Gladwin et al., 1995), approach to discern what business and marketing strategies might look like if they were underpinned by environmental and ecological science. In particular, an ecocentric epistemology offers an alternative cultural and mental framework that focuses on the whole system or ecosystem and the balance of all species and elements (i.e., rocks, water, and gases of the atmosphere). Humans thus move from their cosmologically central and egocentric 
position, in which the whole of nature exists only for their exploitation with no intrinsic value (Gladwin et al., 1995; Kilbourne, 1998; Kilbourne et al., 2002; Purser et al., 1995), to a more balanced site in the larger system that demands greater appreciation of and respect for other species and planetary resources (Du Nann Winter and Koger, 2004; Porritt, 2007; Shrivastava, 1995).

\section{Organization of the article}

In this article we take an ideological, epistemological, yet strategic and practical approach to our work, which is driven by the potential reality of our modern lack of ecological sustainability. First, we investigate the basis of our knowledge about the world by considering, independently, anthropocentrism and ecocentrism as potential epistemologies in which to ground the ecological sustainability concept. Pursuing the ecocentric line of inquiry, we then explore extant literature on ecocentric strategy development —at corporate, business, and marketing levels—so that we can begin to understand the theoretical framework in which we are working, and establish our investigation within this literature.

Following that, we extrapolate from the literature and from the two epistemological ideologies to conceptualize business strategies for ecological sustainability, as they relate to the development of marketing strategy. Transitional and transformational business and marketing strategies for ecological sustainability emerge from this discussion; and they represent one of the primary contributions of this article. Transitional strategies emerge from an anthropocentric epistemology, and transformational strategies emerge from an ecocentric epistemology.

Then we examine what strategic business and marketing solutions might look like from an ecocentric perspective. This is an important contribution because of the imperative of finding sustainability-based solutions, as well as focusing on problems. It is also key to find strategic 
solutions that are framed in ecocentric epistemology and ideology (for ecological sustainability) rather than relying solely on existing anthropocentric strategic solutions, models, and frameworks, which could now be regarded as outdated.

This leads us to the primary contribution of this article which is to examine how ecocentric thinking can influence strategic marketing. In the ecocentric strategic marketing vision section we make both a conceptual and practical contribution to illustrate how ecocentric marketing strategy may be adopted. We then return to our conceptual contribution to explore how ecocentrism can be embedded within (and reconceptualized on) strategic marketing as a domain and marketing strategy as an organizational activity, and what this might look like as a set of universal foundational marketing premises and principles based on ecological science and thus ecocentrism. We also offer a definition of ecocentric transformational marketing strategy. We finish by discussing the managerial and scholarly relevance of our research and conclude by reflecting on the approach taken and the primary objective of finding new research linkages between strategic marketing and ecological sustainability.

Throughout we take the position that ecocentrism embraces and represents ecological science and thus ecological sustainability, and that anthropocentrism embraces and represents sustainable development and other human-oriented approaches to sustainability.

We also reflect on and use the term epistemology, as it relates to the theory of knowledge, and how we as individuals try to bring meaning, understanding, and interpretation to the world around us. The term epistemology is itself a social construction, created by and for human use. The term ideology, on the other hand, broadly is used to encompass our human ability for visionary speculation — to create a future ideal—as an alternative way of thinking about and viewing the world. Thus consideration of an ecocentric epistemology and ideology for strategic 
marketing allows us to conceptualize what strategic marketing activity might look like in the future if it were based on ecocentric knowledge and understanding (knowledge and understanding of the ecological sciences and ecological sustainability) and how we can begin to map out what that future might look like.

\section{Anthropocentric and ecocentric epistemologies}

In this section we consider anthropocentric and ecocentric epistemologies as they relate to different ways to view the concept of sustainability. This discussion is not designed to be outwardly polemic but rather to provide a choice of platforms from which to consider different forms of sustainability. Whilst anthropocentric and ecocentric perspectives provide two different views there also exists epistemological degrees and variations between these two.

\section{Anthropocentric epistemology}

Anthropocentric epistemology embraces the notion of human exemption: Unlike other species, humans are exempt from the constraints of nature, and the whole of nature exists primarily for human use with no inherent value of its own. This notion is reflected in widespread beliefs about the benefits of abundance and progress, pursuit of unlimited growth and prosperity, faith in science and technology, and commitments to a laissez-faire economy, limited government planning or intervention and private property rights. This modern Western worldview posits that land not used for economic gain is wasted and that people have the right to develop land and do with it as they see fit (Kilbourne, 1998; Purser et al., 1995).

Purser et al. (1995) propose limits to anthropocentrism, including primarily that it offers no overall survival plan (see also Kilbourne, 1998). A consumption rhetoric, also termed helpfully the "social logic of consumerism" by Smart (2010), is a means to an end that lacks an end-point, with no overall goal—human or otherwise. Economic growth, thus, continues unlimited and 
unchecked, until complete destruction of the physical environment and natural resource base occurs (Diamond, 2006). This outcome, as the ultimate achievement of anthropocentrism, implies an incorrect understanding of the purpose of individual human existence (Capra, 2004; Du Nann Winter and Koger, 2004; Zohar and Marshall, 2000, 2004).

Yet the anthropocentric ideology has become embedded in human society, likely because it helps those who benefit most maintain their power and wealth. It also comprises three specific elements: a linear perspective, a camera theory of knowledge and the social construction of a human-nature dualism (Banerjee et al., 2009; Purser et al., 1995; Starik and Marcus, 2000). The former two elements both point to a spectator epistemology, which purportedly involves unmediated seeing or passive mirroring of reality. The third element assumes humans are above other species, according to a socially constructed hierarchy (Purser et al., 1995; Schultze and Stabell, 2004). This conceptual differentiation allows people to construe nature as unlike them, which offers support for the claim that humans are morally superior to non-humans and thus justified in dominating nature (Purser et al., 1995). Such an anthropocentric attitude essentially denies any inherent worth to nature (Gladwin et al., 1995).

As the separation or duality of humans and nature continues to gain social traction, people's (the general public) lack of physical and psychological connection with the biophysical world creates problems in that individuals, especially in Western, developed economies, often lack a basic understanding, or appreciation, of how nature functions, its importance to their everyday lives (and their survival), and an understanding and respect for its ultimate power over human existence (Du Nann Winter and Koger, 2004). This basic lack of connection and the persistent view that human needs are superior and more urgent than the needs of other species or of the biosphere is dangerous and destructive (Dunlap et al., 2000; Kilbourne, 1998; Purser et al., 
1995). This reductionist, deconstructionist and empirical science orientation of the anthropocentric ideology reflects its rational, instrumental, egocentric, and exemption value base (Purser et al., 1995), as we depict in Table 1.

\section{Insert Table 1 about here}

The anthropocentric epistemology also leads society to embrace a particular set of cultural values, metaphysical beliefs, institutions, habits, and so forth, which collectively provide social lenses for interpreting the social world according to a dominant social paradigm (Kilbourne, 1998). There is no consensus on what constitutes the dominant social paradigm of Western industrial societies, but to dominate, it must be held only by dominant groups in society, not necessarily by a majority of people (Cotgrove, 1982). The dominant social paradigm then can legitimize and justify prevailing institutions that serve the interests of dominant groups, providing a mechanism for re-enforcing specific social, political, or economic courses of action. The essential requirement is to embed the dominant social paradigm in society, in which case its directions and justifications become accepted as truth that demands no further examination.

Kilbourne (1998) cites two dominant social paradigm domains: the socio-economic domain, which incorporates political, economic, and technological dimensions, and the cosmological domain, which refers to larger questions of existence, such as the structure (atomistic-holism), relation (domination-submission) and organization (anthropocentric-ecocentric) of nature or the significance of nature itself. These background assumptions, largely unquestioned and/or unexamined, produce particular values, beliefs and behaviors (Kilbourne, 1998). We attempt to address some of these larger cosmological questions as a means to suggest an alternative direction for strategic marketing theory development.

\section{Ecocentric epistemology}


Ecocentrism, broadly, is characterized by the belief that ecosystems have inherent worth for maintaining planetary homeostasis and all life. Through notions of holism, integration, and synthesis, it asserts that human cultural systems must function within the safe operating limits dictated by ecosystems. Ecosystem integrity is paramount; animals and plants have as much right to exist as humans. It also establishes an underlying belief in the need for responsibility and stewardship toward plants, animals, wilderness and the planet (Dunlap et al., 2000; Purser et al., 1995).

The ecocentric epistemology is an alternative way of experiencing and evaluating the world, and it has acquired multiple names, including the new ecological paradigm (Dunlap et al., 2000) and the ecocentric responsibility paradigm (Purser et al., 1995), but it consistently represents a radical departure from anthropocentric epistemology. Ecocentric philosophers view anthropocentric assumptions as the root cause of environmental problems, so they express their explicit concern with emancipating ecosystems from the effects of human mismanagement, overuse, and exploitation. To foster deeper appreciation for the intrinsic value of nature, ecocentrists seek to effect change at the levels of human beliefs, values, ethics, attitudes, behaviors, and lifestyles. The relevant values align with movements to reduce human population growth and human consumption, preserve wilderness areas, protect the integrity of biotic communities, and restore ecosystems to a healthy state of equilibrium, which Spilhaus (1972) calls ecolibrium.

Furthermore, an ecocentric epistemology reflects an Arcadian tradition of ecology that takes a normative and non-intrusive attitude toward the subject of study (Worster, 1977). For example, Odum (1953, p. 9) described an ecosystem as "an entity or natural unit that includes living and nonliving parts interacting to produce a stable system in which the exchange of materials 
between the living and nonliving parts follows circular paths," such that they exist at various levels and sizes. The largest ecosystem is the entire Earth; at the level of the biosphere, other ecosystems operate (Lovelock, 2000). Odum's ecosystem concept offers a type of methodological holism (Table 1, row 4), because organisms cannot be studied in isolation of the role and function they play. Furthermore, Odum recognizes that human beings are key components of ecosystems, though destructive ones.

Ecosystems need to be biologically diverse to be ecologically sustainable and where member organisms can flourish in their respective niches, free from distress. This scenario allows for selfrenewal, self-management, and self-regulation in a dynamic, indefinite, self-perpetuating, closedloop cycle (Borland, 2009a). Healthy ecosystems do not require repair, upkeep, or management by humans, whereas unhealthy ecosystems demand environmental management, constant doctoring, and engineering. King (1995) discusses the importance of avoiding ecological 'surprises,' activities initiated by humans or natural phenomena that can destabilize ecosystems; and Rolston (1994, p. 71) realizes that from an ecocentric perspective, the main issue is conserving natural values that do not put the health of ecosystems at risk, such that healthy ecosystems "produce natural values, as well as support human cultural values, and such productivity and support is the bottom line." This ideological shift places primary emphasis on the value of ecosystem integrity. Human cultural development can be encouraged if it sustains ecological integrity or ecosystem health (Diesendorf and Hamilton, 1997; Linnenluecke and Griffiths, 2010). That is, the focus is on ecological sustainability, rather than sustainable development or environmental management; ecological sustainability ultimately supports human existence (Bansal and Roth, 2000; Borland, 2009a; Porritt, 2007). Gunderson and Holling (2002) examine the coupling of human-environment systems using the 'resilience conceptual 
framework,' the 'adaptive cycle metaphor,' and the concept of 'panarchy' or nested sets of adaptive cycles. Wallerstein (1993) also analyzes 'world systems' as they relate to humanecological interactions.

In Leopold's (1970) vision, humans evolve as they shift from an anthropocentric to an ecocentric ethic. Zohar and Marshall (2004) also claim higher levels of spiritual intelligence result from ecocentric and sustainability values, suggesting a much clearer meaning and purpose for human existence. The holism of the ecocentric epistemology emphasizes the importance of the whole ecosystem, not individual members or parts, and removes humans as the sole locus of value. Such a radical change in beliefs, values, and ethics can be psychologically challenging (Ketola, 2008; Naess, 1995), though the more rooted individuals become in understanding its principles, the more logical ecocentrism seems-to the point that anthropocentrism ceases to make sense. An ecocentric epistemology is not misanthropic (Gladwin et al., 1995; Iyer, 1999) but rather amounts to an ideological and psychological, personal, and collective shift, with a concomitant recognition of the physical constraints on individuals and organizational systems. In the next section we pursue ecocentric thinking and explore some of the extant literature surrounding ecocentric strategy development at corporate, business, and marketing levels. In so doing, we begin to understand the theoretical frameworks with which we are working, and try to establish our investigation within this literature.

\section{Ecocentric strategy development}

Conventional definitions of strategic marketing and marketing strategy reflect an anthropocentric epistemology. Varadarajan (2010) distinguishes definitions of marketing strategy as either broad, with consideration of strategic resources and assets and their links to business and corporate strategy, or narrow, such that they focus on differences between marketing strategy and tactics. 
Yet his definition of strategic marketing as a domain and marketing strategy as an organisational activity omits the essential role of the environment in providing natural resources and assets that are the source of all products and services. Varadarajan acknowledges just that the "high level of interest among marketing academics and practitioners in sustainability-related issues is destined to have a significant impact on the nature and scope of the marketing discipline" (Varadarajan, 2010, p. 122). When examining the relationships among corporate strategy, business strategy, and marketing strategy, Varadarajan (2010) also suggests "strategic marketing decisions can be viewed as an organization's decisions in the realm of marketing that are of major consequence from the standpoint of its long-term performance." This close relationship of the three strategy levels is essential for corporate success, including an ecocentric corporate strategy.

Yet strategy development that embraces ecological sustainability is virtually missing from corporate, business, or marketing strategy literature, especially any approaches framed in ecocentric epistemology (Borland, 2009a; Dunlap et al., 2000; Purser et al., 1995; Shrivastava, 1995; Stead and Stead, 2004). Purser et al. (1995) place ecocentric theory development in its infancy stage and note that often it is regarded as unrealistic, though that perception may reflect the general lack of understanding of how to couple the science of ecological sustainability with the needs of commercial industry and human materialism. The challenge thus becomes to develop theory and practice that integrates the dualism of nature and human needs. Purser et al. (1995) claim ecocentric theory development should proceed separately from existing anthropocentric theory development until it achieves sufficient legitimacy, coherence, and maturity. They assert the most urgent task at hand is assuring that the ecocentric responsibility paradigm enters into any formulation of organizational theory development and management practice and that organization-environment relationships foster ecological sustainability. 
Shrivastava (1995) argues that corporations have a responsibility to incorporate ecological sustainability into their logics, as an integral aspect of their effectiveness. Because corporations have the knowledge, resources, and power to bring about enormous changes in the Earth's ecosystems, government policy and consumer behavior in tandem could lead to true ecological sustainability. He also identifies benefits of ecological sustainability to corporations (Shrivastava, 1995), in reduced long-term risk associated with resource depletion, fluctuating energy costs, or product liabilities, as well as pollution and waste management. Yet Shrivastava (1995) recognizes that a move to ecological sustainability requires an overall value reorientation in both society and corporations, from the current economic rationality to a broader ecological rationality focused on the long-term survival of all species (see Table 1, row 3).

In line with such theory, we focus on incumbent corporations and their role in ecological sustainability. Corporations are the primary engines of economic development (Gladwin et al., 1995), with the financial resources, technological knowledge, and institutional capacity needed to implement new strategies (Banerjee, 2002; Kilbourne, 2008). Examining ecological sustainability at organizational and functional levels also is necessary but underdeveloped, especially considering the scale of issues involved (Kilbourne, 1998; Purser et al., 1995; Shrivastava, 1995; Stead and Stead, 2004). We acknowledge though that corporations are only one ecological sustainability gap; consumers and governments must be willing to participate too, but a discussion of these two groups is beyond the scope of our article.

In the next section of this article we extrapolate-from the literature and from anthropocentric and ecocentric epistemologies_- business strategies for ecological sustainability as they relate to the development of marketing strategy. What emerges are two strategy types, one based on 
anthropocentric thinking and one based on ecocentric thinking: transitional and transformational strategies.

\section{Business strategies for ecological sustainability}

Transitional strategies (Table 1, column 2) maintain an anthropocentric epistemology and the dominant social paradigm, and can be easily identified in the modern corporate arena. They are characterized by now-familiar parlance: reduce, reuse, recycle, and regulate (the 4Rs). They are also associated with the adoption of eco-efficiency and socio-efficiency management (McDonough and Braungart, 2002; Young and Tilley, 2006). These transitional strategies are linear, cradle-to-grave, open-loop, dualistic approaches that create continuous improvement and incremental change (Hart and Milstein, 1999), driven by a desire for competitiveness or differentiation. They do not, however, encourage natural diversity, creativity, or productivity. In this sense, they represent anti-sustainability and act merely to slow down the eventual death and destruction of resources and habitats of which corporations, consumers (citizens in the ecocentric view), and government are stakeholders.

Transformational strategies (Table 1, column 3) instead embrace ecocentric epistemology and the ecocentric responsibility paradigm (Purser et al., 1995). By working within the constraints of natural ecosystems, transformational strategies incorporate eco-effectiveness and socioeffectiveness (McDonough and Braungart, 2002; Young and Tilley, 2006) and represent holistic, cradle-to-cradle, systems-based, closed loop, visionary approaches that create discontinuous change and creative destruction (Hart and Milstein, 1999). They can be competitive but achieve better firm performance through collaborative, innovation-oriented strategic alliances (Child et al., 2005; Hall and Vredenburg, 2003; Nidumolu et al., 2009; Porter, 2008; Porter and van der 
Linde, 1995a, 1995b; Pujari et al., 2003, 2004; Seitz and Peattie, 2004; Senge and Carstedt, 2001; Sharma et al., 1999; Slater et al., 2007).

Another quality sets transformational strategies apart from other strategic approaches: They work with nature rather than against it and thus require significant scientific, psychological, and strategic understanding by the focal company. The progression toward a transformational strategy is not necessarily smooth and may require a step-based change in identity and leap of faith. Just as transformation at an individual level requires a fundamental shift in the depth and level of the individual's learning and understanding, usually precipitated by a negative, lifechanging experience (Borland, 2009b; Du Nann Winter and Koger, 2004; Zohar and Marshall, 2000, 2004), at the collective, corporate level, the experience is often equally life-changing for the very orientation of the company. The PVC manufacturer Hydro Polymers, for example (Leadbitter, 2002), experienced the threat of closure from the significant negative publicity it suffered as a result of some of its activities before it changed to an ecocentric transformational business strategy for sustainability.

Understanding ecocentric, transformational business strategies is central to developing strategies for ecological sustainability, but our recognition of transitional and transformational macro business strategies suggests some key questions:

1. Are transitional and transformational business strategies mutually exclusive or progressive?

2. Is a transitional strategy likely to become embedded in a firm, such that it can no longer progress to a transformational strategy?

3. Does a transformational strategy require the company to go through a transformation?

Transitional and transformational strategies are not mutually exclusive; a company might initially adopt a transitional strategy that encourages eco-efficient behaviors, such as the 4Rs, to 
introduce employees, suppliers, customers, and other stakeholders to new attitudes, values, and behaviors. In the process, the leap to a transformational strategy becomes easier; if the firm applies transitional behavior to eco-effectiveness, for example, using only biological and technical nutrients (which we define subsequently) (McDonough and Braungart, 2002), the difference likely becomes transformational. A transitional strategy thus can be a first step toward a transformational strategy.

Yet it is also possible to adopt a transformational strategy without ever introducing a transitional strategy; equally, some firms may become stuck in a transitional mode without ever progressing to a transformational strategy. An embedded transitional mode is dangerous (Hart, 1995), comparable to simply continuing with business as usual in a conventional business and marketing mode.

Finally, the process of transformation usually is led by an individual within an organization, rather than the organization per se. Ecocentric transformational leadership is a central element of the success of corporate ecological sustainability (Borland, 2009a; Capra, 2004; Closs et al., 2011; Stead and Stead, 2004; Zohar and Marshall, 2004). Its further discussion is beyond the scope of this article though.

Focusing in particular on transformational strategies, in the following section, we begin the process of outlining what ecocentric business and marketing strategy solutions might look like so that we can move forward at a practical level in designing new ecocentric marketing strategy. This section focuses on solutions rather than problems and is framed within ecocentric epistemology and ideology.

Ecocentric business and marketing solutions 
Ecocentric business and marketing solutions evolve from ecocentric business strategies. In particular, transformational business strategies operate most effectively at an industry level, and then at the individual company level (Bansal and Roth, 2000; Hart and Milstein, 1999). By creating an ethos of cooperation, collaboration, and innovation across competing firms, ecocentrism can support future industry development and survival (Child et al., 2005; Hart, 1995; Nidumolu et al., 2009; Shrivastava, 1995). McDonough and Braungart (2002), Stead and Stead (2004), Hart (1997, 2007) and Hart and Milstein (2003) have contributed to the development of ecocentric business and marketing solutions, though none of them frame their work according to an ecocentric epistemology. Their approaches are varied, but in combination, they reflect a logic and flow that makes strategic sense.

McDonough and Braungart (2002) assert that the main issue for marketing ecologically sustainable products and services is the design of physical products. Many household products give off high levels of noxious and dangerous substances, and industry disposes of vast amounts of dangerous chemicals that are crippling the environment and harming human health (McDonough and Braungart, 2002). These authors conclude that industrial ecosystems should enhance and add to their local environment, rather than poisoning the environment and human health. Their mantra illustrates that product conception, development, manufacture, use, and disposal must follow holistic, systems-based, closed-loop principles that prevent pollution and waste.

Using the term eco-effectiveness, McDonough and Braungart (2002) also suggest that all products should be produced from two types of materials: biological nutrients and technical nutrients. Biological nutrients biodegrade and can be returned to the biological cycle without inflicting any damage; technical nutrients do not biodegrade, but can be circulated continuously 
through the industrial cycle, which eliminates waste and pollution and reduces resource use. This more positive outlook for the future could allow humans to continue with their current lifestyles and quality of life. In providing this cradle-to-cradle, closed-loop, transformational approach to product design, strategic marketing, and corporate vision, McDonough and Braungart (2002) also offer a transformational solution to managing supply chains.

In another example, Stead and Stead (2004) emphasize three value chain models. Type I is a conventional, cradle-to-grave supply chain; type II is a transitional version that incorporates recycling activity; and type III, of most interest to ecocentric business and marketing, depicts a cradle-to-cradle, closed-loop, value chain in an open living system economy, with no waste or pollution. Using only biological nutrients, renewable energy sources, and technical nutrients in industrial systems, it produces safe biological wastes that get reabsorbed into the biological system. However, they recognize that a supply chain using only biological or technical nutrients needs new manufacturing technology and processes, including clean technologies that are yet to be developed (Hart, 1997; Hart and Milstein, 2003).

Government support for such transformations will be essential, coupled with industrial collaboration. However, the current global financial predicaments, turbulent nature of major industrial economies, and exponential population growth in developing and emerging economies suggest that it may also be a way out of economic and environmental devastation, in a more positive and life-enhancing way than has been proposed previously. The transformation to this type of system is challenging and requires major research and development investments.

The contributions of McDonough and Braungart (2002) and Stead and Stead (2004) also can be combined with the recommendations of Hart (1997, 2007) and Hart and Milstein (2003). Their sustainability portfolio matrix offers companies a roadmap or vision for sustainable change 
in four stages: pollution prevention, product stewardship, clean technologies, and sustainable vision. The stages are progressive and offer increasing challenges to a firm's ecocentric strategic marketing activity, as it moves toward a sustainability vision. Pollution prevention and clean technologies affect the internal operation of the company; product stewardship and sustainable vision also engage external elements, such as suppliers, customers, and other stakeholders. Even in the first stage, the process can be difficult to implement at a practical level, because it demands not just pollution reduction (which would be transitional) but pollution elimination. Therefore, to enter the portfolio at all is a challenging task, aligned with McDonough and Braungart's (2002) eco-effectiveness or Stead and Stead's (2004) type III value chain.

In integrating these three closed-loop, systems-based, transformational approaches, we offer a vision of ecocentric business and marketing solutions that incorporates the redesign of products (and services) using only biological and technical nutrients as components and materials. Such usages enable the supply chain - from source to consumer and beyond - to close its loop and avoid leaking or leaching any unwanted or dangerous substances into the environment. It also closes the waste loop such that the transfer of energy and nutrients represents a continuous process from cradle-to-cradle (type III). In Hart's (1997) sustainability portfolio matrix, one then observes that the type III, cradle to cradle approach succeeds in achieving pollution prevention and product stewardship; it also requires clean technologies to be developed and provides a clear and unambiguous ecological sustainability vision that could be applied to firms in developed nations, emerging economies, developing nations and base-of-the-pyramid societies worldwide (Hart, 2007; London, 2009; Prahalad and Hart, 2002).

In the next section, we map out what an ecocentric strategic marketing vision might look like conceptually, and provide case examples and a managerial tool to help academics and 
practitioners identify ecocentric marketing strategy. Then, as part of future conceptual and theoretical development, in the final section of this article, we explore the general applicability of ecocentric business and marketing strategies, proposing six universal foundational premises and principles, and a definition of ecocentric transformational marketing strategy based on ecological science and thus ecocentrism. These next two sections together represent the primary conceptual contribution of this article.

\section{An ecocentric strategic marketing vision}

The preceding sections provide key input to inform ecocentric marketing strategies, which should lead to an ecologically sustainable approach to product conception and design that ensures the outputs do not damage the environment or people. Such strategies also should close the loop in supply chains, changing or eliminating the notion of waste; offer opportunities for product differentiation and thus competitive advantage; and provide a vision of what a truly ecologically sustainable society would look like, filled with ecocentric products and services.

Ecocentric marketing strategy is transformational in nature and follows the format of a transformational business strategy (Table 1, row 7): These strategies are ecologically sustainable and pursue an eco-effective, socio-effective route that is closed-loop, cradle-to-cradle, and systems-based. They encourage health and abundance for all species, because no damage gets inflicted on the physical environment or human health.

If a company adopts an ecocentric transformational marketing strategy, its sphere of influence should extend to consumers, suppliers (Sharma and Vredenburg, 1998), and other firms in the

same industry, creating leadership and first-mover advantages (Unruh and Ettenson, 2010). At a strategic level, firms must first realize the differences between transitional and transformational strategies, then make a conscious decision to adopt a transformational strategy. Transitional 
strategies may provide a useful first step, but they also are tantamount to greenwashing and maintain a destructive, business-as-usual approach. It is therefore essential that a company embrace a vision to move beyond a transitional strategy if it genuinely aims to contribute to the survival of all species and the environment and hopes to make its strategic marketing activity part of the solution rather than part of the problem. We therefore introduce some practical steps for implementing ecocentric transformational marketing strategies.

It is important to remember that the move from conventional through transitional to a transformational strategy can be stepwise. If we refer to a conventional strategy as $\mathrm{T}_{0}$, a transitional strategy as $\mathrm{T}_{1}$ and a transformational strategy as $\mathrm{T}_{2}$, we might depict a continuum, with $\mathrm{T}_{0}$ at one end, $\mathrm{T}_{2}$ at the other and $\mathrm{T}_{1}$ in the middle of the line (Figure 1). Alternatively, we could create a grid, with $\mathrm{T}_{0}, \mathrm{~T}_{1}$ and $\mathrm{T}_{2}$ across the top and the different strategic marketing/business activities along the side (Figure 1). For each product we can then assign individual activities, such as product design, to conventional, transitional, or transformational categories. This grid produces a numerical score that reflects the status of each product. With this progressive, aspirational approach to strategic marketing, marketing departments and companies gain the opportunity to assess their progress toward an ecocentric, transformational strategy and evidence to bolster their claims that they are working toward ecological sustainability in a genuine and life-enhancing way. Of course, firms are unlikely to adopt any strategic approach that does not provide secure financial returns. Ecocentric transformational strategies change the very nature of the product being sold, such that they potentially can enhance financial returns through genuine sustainability-based differentiation and competitive advantage.

\section{Insert Figure 1 about here}

\section{Case examples}


A review of existing companies does not turn up companies that have completely adopted an ecocentric transformational strategic approach, though many companies are making genuine attempts to be sustainability led. A particularly interesting example, considering its prior transgressions, is Nike. Its line of casual shoes, Nike Considered, appear to follow an ecocentric approach in that these shoes are made of vegetable-tanned leather, which eliminates toxic chromium (traditionally used to tan leather) from the waste pipeline. After its product usage, the leather will decompose naturally in compost heaps to become food for other species (biological nutrient) and leave no toxic residues. The soles of the shoes are made from recycled rubber and are infinitely recyclable if returned to the company (technical nutrient). Because there are no adhesives involved in constructing the shoes, production workers in factories and the environment experience no toxic effects. The components of the shoe are designed to "pop" together and can be completely disassembled for easy recycling or reuse. The shoes are desirable to consumers, and demand is strong. Finally, all their materials are sourced within 200 miles of the factories that produce them to reduce fuel consumption. These shoes thus score high in Figure 1 on the product concept, product design, component materials, manufacture, and consumer demand categories; their score is somewhat lower for component and retail distribution. Although it represents only one product line at this stage, Nike Considered shoes provide interesting evidence that an international conglomerate can experiment successfully with ecocentric models and strategies.

Herman Miller, the office furniture manufacturer, has developed a range of office chairs that follow similar principles. The seats are made of fabric constructed solely from biodegradable materials; if added to an aerobic composting environment, they will biodegrade naturally and leave no toxic residues. The frames and plastic components of the chairs are constructed such 
that they can be disassembled, recycled, or reused indefinitely, without down-cycling, in a closed-loop industrial cycle. Thus they create no waste and eliminate the need for virgin raw materials. Closing the manufacturing loop changes the emphasis on the value of component parts. At the end of their life, instead of products being regarded as waste to be sent to landfill, manufacturers become highly interested in their return, because they are the input for the next round of production. The components are valuable raw materials for new products, which makes the relationship between manufacturer and material more positive. This strategy also can induce other changes in the marketing strategy, such that the firm might become more interested in renting products to consumers rather than selling them, to ensure it receives the products back at the end of their productive life in a particular iteration (McDonough and Braungart, 2002).

Transitional and transformational strategies also represent an opportunity to adopt existing sustainability-orientated management tools that are widely recognized. In particular, lifecycle analysis and biomimicry are examples of management tools that can be applied at either a transitional or transformational level; the difference being whether each is used in a cradle-tograve or a cradle-to-cradle fashion and thus whether each is conducted as a closed-loop exercise or not. Closed loop, cradle-to-cradle lifecycle analysis or biomimicry are tools that are ecocentric and can be used within transformational strategies. Open-loop, cradle-to-grave lifecycle analysis and/or biomimicry are anthropocentric and are, thus, tools that would fit with transitional strategies. Therefore, lifecycle analysis and biomimicry have the potential to fit either strategy type.

\section{Ecocentric strategic marketing premises}

Returning to the work of Varadarajan (2010), he identifies some foundational premises for marketing strategy, such that to be universal, they must be generalizable across products, 
markets, and time horizons. He also articulates two key purposes of a marketing strategy: to enable a business to achieve and sustain a competitive advantage and to influence consumers' preferences. We add another purpose: A marketing strategy must incorporate the physical environment as the source of physical well-being for all species, as well as the source of all products and services. Marketing strategies then become grounded in physical, scientific reality, as well as human social reality. They will thus become more stable and sustainable, in both commercial and ecological senses.

Ecocentric transformational marketing strategies meet Varadarajan's (2010) foundational premises to provide a competitive advantage, create organisational assets, nurture exchange relationships, influence consumers purchasing behaviour, leverage new points of differentiation, and enhance the salience of non-price criteria. We propose six additional universal premises, grounded in ecological science, to which ecocentric transformational marketing strategies must also adhere:

1. Adopt the design, manufacture, consumption and disposal of eco-effective products and services.

2. Utilize energy from renewable resources such as solar and bio-gas, at both commercial and domestic levels.

3. Engage in habitat reconstruction and the preservation of and respect for all species.

4. Educate people about their individual responsibility toward the environment and other species.

5. Seek financial investments from governments that support eco-effective industry, firm, and product development for future economic stability, collaboration, and competitiveness. 
6. Promote sensible family size worldwide, with no more than two children per family, and support the adoption of orphans.

In addressing these premises, we propose a definition of ecocentric transformational marketing strategies:

Companies that satisfy the needs of industrial and consumer markets remaining within biophysical constraints, only exploiting resources at a rate at which they can be sustainably maintained, recovered or replenished in cradle-to-cradle, closed-loop ecological systems.

From this definition, it is also possible to summarize key ecocentric transformational marketing strategy principles as follows:

- Product design and innovation from ecological core competencies.

- Value from sustainability values.

- Competitiveness from ecological stability.

- Collaboration from shared sustainability goals.

- Solutions from shared sustainability understanding.

- Vision from ecocentric marketing leadership.

\section{Managerial relevance and further research}

It is possible, now, to reconsider our original research question: Can strategic marketing be reconceptualized to reflect ecocentrism and ecological sustainability? We answer our question in the affirmative, which then suggests the need to consider its relevance and opportunities for managerial practice and research. At a broad level, we offer managers and researchers a clear, easy to apply approach for categorizing sustainability strategies. Much ambiguity persists as to what constitutes a strategy for sustainability and what does not. We propose a foundational conceptual framework that will allow researchers and managers to identify quickly whether a 
business is adopting a transitional or transformational sustainability strategy and thus how the firm might be guided to develop its strategy further. Auditing their current position in this way also enables firms to move forward. Identifying the path from transitional to transformational sustainability strategies will help firms and their different functions produce a sustainability vision, mission, values, goals and objectives.

The clear delineation of eco-efficiency and eco-effectiveness in transitional and transformational strategies also may support the future development of a universal "traceability mark" for products and services that claim to be sustainable. Firms could differentiate themselves according to their actual ecological sustainability credentials. As consumers become increasingly discerning and information savvy regarding products' provenance, such a logo, through becoming a trust mark, could provide a source of competitive advantage and improve corporate reputation.

Finally, firms and their functions can identify themselves clearly according to the two sustainability strategies. They then may seek out like-minded partners as suppliers, distributors, retailers and so forth, in their network of operations. In particular, firms following a transformational sustainability strategy can create transformational networks of firms.

At a more focused level, this research provides opportunities to examine a firm's approach to the sourcing, product design, manufacture, distribution, usage, and disposal of particular products. Each supply chain can gather evidence of the existence of a transitional or transformational strategic approach to the creation of products and the elimination of carcinogens, mutagens, and persistent and accumulative environmental toxins. In turn, opportunities arise to examine, in detail, whether each firm tends to adopt and then persist with a 
transitional or transformational strategy or if it is possible to move from one to the other, and which mechanisms enable such shifts.

A wealth of research opportunities thus emerge for academics to establish, both qualitatively and quantitatively, whether firms adopt either sustainability strategy, what their characteristics are, how successful firms have been, and what their future plans are. Further theoretical research also should test the application of the ecocentric universal premises and principles and both sustainability strategy types. Thus the managerial relevance and research opportunities associated with ecocentric transformational marketing strategies are significant. In our view, this new approach to strategic marketing opens a new area of inquiry and suggests productive avenues for research and management practice in coming years. Finally, further research could look toward recent manifestations of an anthropocentric ideology, terminology such as anthropocene and resilience that suggest a different view on ecosystems and human-nature interactions. Whilst the focus here has been on the epistemological debate and thus having left out discussion of geological time zones, we believe that the suggested research avenue potentially could add to the grounding for the epistemological endeavor of this article.

\section{Conclusions}

This article has achieved several key outcomes. First, we advance the approach presented by Purser et al. (1995) by identifying business and marketing strategies that reflect ecocentric epistemology and ecological sustainability. Although still descriptive at this stage, it represents, to the best of our knowledge, the first attempt at such an identification.

Second, we have adopted Kilbourne's (1998) cosmological domain to address some of the larger questions of existence-such as the significance of nature, as well as its structure (atomistic-holism), relation (domination-submission) and organization (anthropocentric- 
ecocentric). We take the perspective of ecocentrism to examine marketing and sustainability and thus challenge some existing beliefs, values, ethics, attitudes, and behaviors that are pervasive in corporate and consumer society. In so doing, we illustrate an alternative way to achieve ecologically sustainable directions in future strategic marketing activity.

Third, we follow the guidance provided by Varadarajan (2010) in defining the foundational premises of strategic marketing. Ecocentric transformational marketing strategies are consistent with Varadarajan's (2010) recommended list; this research also has identified six universal premises and six strategic principles that are uniquely applicable to ecocentric transformational marketing strategies.

Fourth, this article reveals the linkages, and thus the bigger picture, between marketing strategy and sustainability and offers a means for studying ecological sustainability as an academic topic in a business school or commercial context. Framed within the ecocentric epistemology, our work connects business strategy with marketing strategy with sustainability, then defines the relationships among the three through the application of an ecocentric, transformational, cradle-to-cradle, systems-based, closed-loop approach. We thus illustrate a new foundational link between marketing and sustainability and define them as connected subjects for further strategic marketing research enquiry and management practice.

\section{References}

Banerjee, S.B.: 2002. 'Corporate environmentalism: The construct and its measurement', Journal of Business Research, 55(3), 177-191.

Banerjee, S.B., Chio, V., and Mir, R.: 2009. Organizations, markets and imperial formations: Towards an anthropology of globalization. Cheltenham: Edward Elgar. 
Bansal, P. and Roth, K.: 2000. 'Why companies go green: A model of ecological responsiveness', Academy of Management Journal, 43(4), 717-736.

Belz, F. M. and Peattie, K.L.: 2009. Sustainability marketing: A global perspective. Chichester: Wiley.

Borland, H.: 2009a. 'Conceptualising global strategic sustainability and corporate transformational change', International Marketing Review, 26(4/5), 554-572.

Borland, H.: 2009b. 'Definitions, theories, drivers and managerial implications: Grounding global strategic sustainability', Academy of Marketing Science Conference, May, Baltimore.

Bosselmann, K.: 1995. When two worlds collide: Society and ecology. Auckland: RSVP Publishing.

Capra, F.: 2004. The hidden connections: A science for sustainable living. New York: Anchor Books.

Child, J., Faulkner, D., and Tallman, S.: 2005. Cooperative strategy. Oxford: Oxford University Press.

Closs, D., Speier, C., and Meacham, N.: 2011. 'Sustainability to support end-to-end value chains: The role of supply chain management', Journal of the Academy of Marketing Science, 39(1), 101-116.

Cotgrove, S.: 1982. Catastrophe or cornucopia: The environment, politics and the future. New York: Wiley.

Cronin, J.J., Smith, J., Gleim, M., Ramirez, E., and Martinez, J.: 2011. 'Green marketing strategies: An examination of stakeholders and the opportunities they present', Journal of the Academy of Marketing Science, 39(1), 158-174.

Curry, P.: 2011. Ecological ethics: An introduction, $2^{\text {nd }}$ ed. Chichester: Wiley. 
Diamond, J.: 2006. Collapse: How societies choose to fail or succeed. London, Penguin.

Diesendorf, M. and Hamilton, C. (Eds.): 1997. Human ecology, Human economy: Ideas towards an ecologically sustainable future. Sydney: Allen and Unwin.

Du Nann Winter, D. and Koger, S.: 2004. The psychology of environmental problems, 2d ed. Mahwah, NJ: Lawrence Erlbaum Associates/Eurospan.

Dunlap, R., Van Liere, K., Mertig, A., and Jones, R.: 2000. 'New trends in measuring environmental attitudes: Measuring endorsement of the new ecological paradigm: A revised NEP scale', Journal of Social Issues, 56(3), 425-442.

Ekins, P.: 2000. Economic growth and environmental sustainability. London: Routledge.

Ellis, N., Fitchett, J., Higgins, M., Jack, G., Lim, M., Saren, M., and Tadajewski, M.: 2011. Marketing: A critical textbook. London: Sage.

Gladwin, T., Kennelly, J., and Krause, T.S.: 1995. 'Shifting paradigms for sustainable development: Implications for management theory and research', Academy of Management Review, 20(4), 874-907.

Grönroos, C.: 2007. In search of a new logic for marketing. Chichester: Wiley.

Guest, R.: 2010. 'The economics of sustainability in the context of climate change: An overview', Journal of World Business, 45(4), 326-335.

Hall, J. and Vredenburg, H.: 2003. 'The challenges of innovating for sustainable development', MIT Sloan Management Review, 45(1), 61-68.

Hart, S.: 1995. 'A natural-resource-based view of the firm', Academy of Management Review, 20(4), 986-1014.

Hart, S.: 1997. 'Beyond greening: Strategies for a sustainable world', Harvard Business Review, 75(1), 66-76. 
Hart, S.: 2007. Capitalism at the crossroads, 2d ed. Englewood Cliffs, NJ: Pearson/Wharton School Publishing.

Hart, S. and Milstein, M.: 1999. 'Global sustainability and the creative destruction of industries', MIT Sloan Management Review, 41(1), 23-34.

Hart, S. and Milstein, M.: 2003. 'Creating sustainable value', Academy of Management Executive, 17(2), 56-67.

Holling, C.S. and Gunderson, L.H.: 2002. 'Resilience and adaptive cycles', in L.H. Gunderson and C.S. Holling (Eds.). Panarchy: Understanding transformations in human and natural systems. Washington, D.C.: Island Press.

Hult, G.T.M.: 2011. 'Market-focused sustainability: Market orientation plus!' Journal of the Academy of Marketing Science, 39(1), 1-6.

Iyer, G.: 1999. 'Business, consumers and sustainable living in an interconnected world: A multilateral ecocentric approach', Journal of Business Ethics, 20(4), 273-288.

Ketola, T.: 2008. 'A holistic corporate responsibility model: Integrating values, discourses and actions', Journal of Business Ethics, 80(3), 419-435.

Kilbourne, W.E.: 1998. 'Green marketing: A theoretical perspective', Journal of Marketing Management, 14(6), 641-655.

Kilbourne, W.E.: 2008. 'How macro should macromarketing be?' Journal of Macromarketing, 28(2), 189-191.

Kilbourne, W.E., Beckman, S.C., and Thelen, E.: 2002. 'The role of the DSP in environmental attitudes: A multinational examination', Journal of Business Research, 55(3), 193-204.

King, A. (1995) 'Avoiding ecological surprise: Lessons from long-standing communities', Academy of Management Review, 20(4), 961-985. 
Leadbitter, J.: 2002. 'PVC and sustainability', Progress in Polymer Science, 27(10), 2197-2226.

Leopold, A. (1970). A Sand County almanac with essays on conservation from Round River. New York, NY: Ballantine (original work published in 1949).

Linnenluecke, M. and Griffiths, A.: 2010. 'Corporate sustainability and organisational culture', Journal of World Business, 45(4), 357-366.

London, T.: 2009. 'Making better investments at the bottom of the pyramid', Harvard Business Review, 90(3), 106-113.

Lovelock, J.: 2000. The ages of Gaia: A biography of our living earth. New York, NY: Bantam.

McDonough, W. and Braungart, M.: 2002. Cradle to cradle: Remaking the way we make things. New York, NY: North Point Press.

Menon, A. and Menon, A.: 1997. 'Enviropreneurial marketing strategy: The emergence of corporate environmentalism as marketing strategy', Journal of Marketing, 61(1), 51-67.

Mittelstaedt, J. and Kilbourne. W.: 2006. 'Macromarketing as agrology: Macromarketing theory and the study of the Agora', Journal of Macromarketing, 26(2), 131-142.

Mort, G.S.: 2010. 'Sustainable business', Journal of World Business, 45(4), 323-325.

Naess, A.: 1995. Self realisation: An ecological approach to being in the world. Perth: Murdoch University Press.

Nidumolu, R., Prahalad, C.K., and Rangaswami, M.R.: 2009. 'Why sustainability is now the key driver of innovation', Harvard Business Review, 90(5), 57-64.

Odum, E.: 1953. Fundamentals of ecology. Philadelphia, PA: Saunders.

Peattie, K.L.: 1999. 'Rethinking marketing: Shifting to a greener paradigm', in M. Charter and J. Polonsky (Eds.), Greener marketing: A global perspective on greening marketing practice, Sheffield: Greenleaf Publishing. 
Porritt, J.: 2007. Capitalism as if the world matters. London: Earthscan.

Porter, M.E.: 2008. 'The five competitive forces that shape strategy', Harvard Business Review, 93(1), 79-93.

Porter, M.E. and van der Linde, C.: 1995a. 'Green and competitive: Ending the stalemate', Harvard Business Review, 73(5), 120-134.

Porter, M.E. and van der Linde, C.: 1995b. 'Towards a new conception of the environment: Competitiveness relationships', Journal of Economic Perspectives, 9(4), 97-118.

Prahalad, C.K. and Hart, S.: 2002. 'The fortune at the bottom of the pyramid', Strategy and Business, 26(1), 54-67.

Pujari, D. Peattie, K.L., and Wright, G.: 2004. 'Organisational antecedents of environmental responsiveness in industrial new product development', Industrial Marketing Management, 33(5), 381-391.

Pujari, D., Wright, G., and Peattie, K.L.: 2003. 'Green and competitive: Influences on Environmental new product development performance', Journal of Business Research, 56(8), $657-671$.

Purser, R.E., Park, C., and Montuori, A.: 1995. 'Limits to anthropocentrism: Toward an ecocentric organization paradigm?' Academy of Management Review, 20(4), 1053-1089.

Rolston, H.: 1994. Conserving natural values. New York, NY: Columbia University Press.

Schaefer, A. and Crane, A.: 2005. 'Addressing sustainability and consumption', Journal of Macromarketing, 25(1), 76-92.

Schultze, U. and Stabell, C.: 2004. 'Knowing what you don't know: Discourses and contradictions in knowledge management research', Journal of Management Studies, 41(4), 549-573. 
Seitz, M. and Peattie, K.L. 2004. 'Meeting the closed-loop challenge: The case of remanufacturing', California Management Review, 46(2), 74-89.

Senge, P. and Carstedt, G.: 2001. 'Innovating our way to the next industrial revolution', MIT Sloan Management Review, 42(2), 24-38.

Sharma, A., Iyer, G., Mehrotra, A., and Krishnan, R.: 2010. 'Sustainability and business-tobusiness marketing: A framework and implications', Industrial Marketing Management, 39(2), 330-341.

Sharma, S., Pablo, A., and Vredenburg, H.: 1999. 'Corporate environmental responsiveness strategies', Journal of Applied Behavioral Science, 35(1), 87-108.

Sharma, S., Starik, M., and Husted, B.: 2007. Organizations and the sustainability mosaic: Crafting long-term ecological and societal solutions. Cheltenham: Edward Elgar.

Sharma, S. and Vredenburg, H.: 1998. 'Proactive corporate environmental strategy and the development of competitively valuable organisational capabilities', Strategic Management Journal, 19(8), 729-753.

Shrivastava, P.: 1995. 'The role of corporations in achieving ecological sustainability', Academy of Management Review, 20(4), 936-960.

Slater, S.F., Hult, G.T.M., and Olson, E.M.: 2007. 'On the importance of matching strategic behaviour and target market selection', Journal of the Academy of Marketing Science, 35(1), $5-17$.

Smart, B.: 2010. Consumer society: Critical issues and environmental consequences. Newbury Park, CA: Sage Publications.

Spilhaus, A.: 1972. 'Ecolibrium', Science, 18 February, 175(4023), 711-715. 
Starik, M. and Marcus, A.: 2000. 'Introduction to the special research forum on the management of organizations in the natural environment: A field emerging from multiple paths, with many challenges ahead', Academy of Management Journal, 43(4), 539-546.

Stead, W.E. and Stead, J.G.: 2004. Sustainable strategic management. New York, NY: M.E. Sharpe Inc.

Unruh, G. and Ettenson, R.: 2010. 'Growing green: Three smart paths to developing sustainable products', Harvard Business Review, 95(3), 94-100.

Varadarajan, R.: 2010. 'Strategic marketing and marketing strategy: Domain, definition, fundamental issues and foundational premises', Journal of the Academy of Marketing Science, 38(2), 119-140.

Varey, R.J.: 2010. 'Marketing means and ends for a sustainable society: A welfare agenda for transformative change, Journal of Macromarketing, 30(2), 112-126.

Varey, R.J.: 2011. ‘A sustainable society logic for marketing', Social Business, 1(1), 69-83.

Wallerstein, I.M.: 1993. World system vs. world-systems, a critique. In A.G. Frank and B. Gills (Eds.), The world-system: Five hundred years or five thousand. London: Routledge.

World Commission on Environment and Development: 1987. (The Brundtland Report) Our common future. Oxford: Oxford University Press.

Worster, D.: 1977. Nature's economy: A history of ecological ideas. Cambridge: Cambridge University Press.

Young, W. and Tilley, F.: 2006. 'Can businesses move beyond efficiency? The shift toward effectiveness and equity in the corporate sustainability debate', Business Strategy and the Environment, 15(6), 402-415. 
Zohar, D. and Marshall, I.: 2000. Spiritual intelligence: The ultimate intelligence. London: Bloomsbury.

Zohar, D. and Marshall, I.: 2004. Spiritual capital: Wealth we can live by. San Francisco, CA: Berrett-Koehler. 
Table 1

\section{Summary of Ecocentric Strategy Development}

\begin{tabular}{|c|c|c|c|}
\hline $\begin{array}{l}\text { Philosophical } \\
\text { Component }\end{array}$ & $\begin{array}{l}\text { Transitional } \\
\text { Strategies }\end{array}$ & Transformational Strategies & Selected Sources (Chronological Order) \\
\hline Epistemology & $\begin{array}{l}\text { Anthropocentric } \\
\text { perspective }\end{array}$ & Ecocentric perspective & $\begin{array}{l}\text { Leopold (1970), Worster (1977), Rolston (1994), Naess (1995), Purser et al. } \\
\text { (1995), Gladwin et al. (1995), Diesendorf and Hamilton (1997), Kilbourne } \\
\text { (1998), Dunlap et al. (2000), Lovelock (2000), Schultze and Stabell (2004) }\end{array}$ \\
\hline Paradigm & $\begin{array}{l}\text { Dominant social } \\
\text { paradigm }\end{array}$ & $\begin{array}{l}\text { Ecocentric responsibility } \\
\text { paradigm or new ecological } \\
\text { paradigm }\end{array}$ & $\begin{array}{l}\text { Purser et al. (1995), Gladwin et al. (1995), Kilbourne (1998), Dunlap et al. } \\
\text { (2000), Lovelock (2000), Kilbourne et al. (2002), Banerjee (2002), Schultze } \\
\text { and Stabell (2004), Banerjee et al. (2009), Borland (2009a) }\end{array}$ \\
\hline Value Set & $\begin{array}{l}\text { Rational } \\
\text { Instrumental } \\
\text { Egocentric } \\
\text { Exemptionalist } \\
\text { Narcissistic } \\
\text { Economic rationality } \\
\end{array}$ & $\begin{array}{l}\text { Emotional } \\
\text { Intrinsic, values-driven } \\
\text { Spiritually advanced } \\
\text { Ecolibrium } \\
\text { Empathetic } \\
\text { Ecological rationality } \\
\end{array}$ & $\begin{array}{l}\text { Spilhaus (1972), Rolston (1994), Shrivastava (1995), Naess (1995), Purser et } \\
\text { al. (1995), Gladwin et al. (1995), Bosselmann (1995), Kilbourne (1998), } \\
\text { Zohar and Marshall (2004), Du Nann Winter and Koger (2004), Stead and } \\
\text { Stead (2004), Porritt (2007), Ketola (2008), Borland (2009a), Linnenluecke } \\
\text { and Griffiths (2010) }\end{array}$ \\
\hline $\begin{array}{l}\text { Scientific } \\
\text { Approach }\end{array}$ & $\begin{array}{l}\text { Reductionist } \\
\text { Deconstructionist } \\
\text { Empirical }\end{array}$ & $\begin{array}{l}\text { Holistic } \\
\text { Synthesis } \\
\text { Systems-based } \\
\text { Homeostatic } \\
\end{array}$ & $\begin{array}{l}\text { Odum (1953), Worcester (1977), Shrivastava (1995), Gladwin et al. (1995), } \\
\text { Capra (2004), Hart and Milstein (1999), Ekins (2000), Lovelock (2000), Zohar } \\
\text { and Marshall (2004), Belz and Peattie (2009), Borland (2009a), Guest (2010) }\end{array}$ \\
\hline Strategy Type & $\begin{array}{l}\text { Transitional } \\
\text { Competitive } \\
\text { Continuous } \\
\text { improvement } \\
\text { Incremental } \\
\text { Linear } \\
\text { Cradle-to-grave } \\
\text { Open-loop } \\
\text { Dualistic }\end{array}$ & $\begin{array}{l}\text { Transformational } \\
\text { Collaborative/innovative } \\
\text { Visionary } \\
\text { Discontinuous } \\
\text { Circular } \\
\text { Cradle-to-cradle } \\
\text { Closed-loop } \\
\text { Integrated }\end{array}$ & $\begin{array}{l}\text { Hart (1995, 1997, 2007), Porter and van der Linde (1995a, 1995b), } \\
\text { Shrivastava (1995), Purser et al. (1995), Gladwin et al. (1995), Sharma and } \\
\text { Vredenburg (1998), Sharma et al. (1999), Hart and Milstein (1999, 2003), } \\
\text { Bansal and Roth (2000), Starik and Marcus (2000), Senge and Carstedt } \\
\text { (2001), Banerjee (2002), Hall and Vredenburg (2003), Pujari et al. (2003, } \\
\text { 2004), Seitz and Peattie (2004), Stead and Stead (2004), Child et al. (2005), } \\
\text { Slater et al. (2007), Sharma et al. (2007, 2010), Porter (2008), London (2009), } \\
\text { Nidumolu et al. (2009), Borland (2009a), Varadarajan (2010), Unruh and } \\
\text { Ettenson (2010), Mort (2010), Varey (2011) }\end{array}$ \\
\hline $\begin{array}{l}\text { Management } \\
\text { Approach }\end{array}$ & $\begin{array}{l}\text { Eco-efficient } \\
\text { Socio-efficient }\end{array}$ & $\begin{array}{l}\text { Eco-effective } \\
\text { Socio-effective }\end{array}$ & $\begin{array}{l}\text { Shrivastava (1995), Purser et al. (1995), Gladwin et al. (1995), Hart (1997, } \\
\text { 2007), Hart and Milstein (1999, 2003), Starik and Marcus (2000), Banerjee }\end{array}$ \\
\hline
\end{tabular}




\begin{tabular}{|c|c|c|c|}
\hline & $\begin{array}{l}\text { Environmental } \\
\text { management, } \\
\text { sustainable } \\
\text { development, } \\
\text { 4Rs - reduce, reuse, } \\
\text { recycle, regulate }\end{array}$ & Ecological sustainability & $\begin{array}{l}\text { (2002), McDonough and Braungart (2002), Stead and Stead (2004), Young } \\
\text { and Tilley (2006), Borland (2009a), Varey (2010), Varey (2011) }\end{array}$ \\
\hline $\begin{array}{l}\text { Marketing } \\
\text { Strategy }\end{array}$ & $\begin{array}{l}\text { Transitional } \\
\text { Incremental } \\
\text { Greenwashing } \\
\text { Business as usual }\end{array}$ & $\begin{array}{l}\text { Transformational } \\
\text { Step change } \\
\text { Ecologically sustainable }\end{array}$ & $\begin{array}{l}\text { Gladwin et al. (1995), Menon and Menon (1997), Kilbourne (1998), Peattie } \\
\text { (1999), Iyer (1999), McDonough and Braungart (2002), Hart and Milstein } \\
\text { (2003), Banerjee (2002), Stead and Stead (2004), Young and Tilley (2006), } \\
\text { Grönroos (2007), Kilbourne (2008), Belz and Peattie (2009), London (2009), } \\
\text { Varadarajan (2010), Unruh and Ettenson (2010), Sharma et al. (2010), Varey } \\
\text { (2010), Closs et al. (2011), Cronin et al. (2011), Hult (2011) }\end{array}$ \\
\hline Overall Purpose & $\begin{array}{l}\text { Human-centric, } \\
\text { business as usual } \\
\text { Sustainable } \\
\text { development }\end{array}$ & $\begin{array}{l}\text { Ecological sustainability } \\
\text { Responsibility for all species } \\
\text { and resources }\end{array}$ & $\begin{array}{l}\text { Purser et al. (1995), Shrivastava (1995), Gladwin et al. (1995), Kilbourne } \\
\text { (1998), Sharma and Vredenburg (1998), McDonough and Braungart (2002), } \\
\text { Stead and Stead (2004), Porritt (2007), Borland (2009a), Varey (2011) }\end{array}$ \\
\hline $\begin{array}{l}\text { Prospects for the } \\
\text { Future }\end{array}$ & $\begin{array}{l}\text { Dystopian } \\
\text { Destruction is the end } \\
\text { game } \\
\text { Only choice remaining } \\
\text { is the rate of global } \\
\text { destruction }\end{array}$ & $\begin{array}{l}\text { Regenerative } \\
\text { Restorative } \\
\text { Systems-based } \\
\text { Productive for business and } \\
\text { nature } \\
\text { Sustainable global society for } \\
\text { all species, with the } \\
\text { recognition of the need to } \\
\text { reduce human population and } \\
\text { consumption }\end{array}$ & $\begin{array}{l}\text { Purser et al. (1995), Gladwin et al. (1995), Kilbourne (1998), McDonough and } \\
\text { Braungart (2002), Du Nann Winter and Koger (2004), Stead and Stead (2004), } \\
\text { Capra (2004), Zohar and Marshall (2004), Porritt (2007), Borland (2009a, } \\
\text { 2009b) }\end{array}$ \\
\hline
\end{tabular}




\section{Figure 1}

\section{Ecocentric Transformational Business and Marketing Strategy Grid}

\section{Continuum Line}

$\mathrm{T}_{\mathrm{o}}$ $\mathrm{T}_{1}$

\section{Strategic Activity for Nike} Considered Shoes

$\mathbf{T}_{\mathbf{0}}$

$\mathrm{T}_{1}$

$\mathbf{T}_{2}$

1. Product Concept

$\sqrt{ }$

2. Product Design

$\sqrt{ }$

3. Component Materials

$\sqrt{ }$

4. Component Material Sourcing

$\sqrt{ }$

5. Manufacturing Processes

$\sqrt{ }$

6. Distribution to Retail Facilities

$\sqrt{ }$

7. Consumer Demand

$\sqrt{ }$

8. Consumer Disposal

$\sqrt{ }$

Total

22 points

Total $=\mathbf{2 2}$ (out of a possible 24).

(A transformational activity $=3$ points, transitional activity $=2$ points, traditional activity $=1$ point.) 